\title{
Levels of Firmicutes, Actinobacteria Phyla and Lactobacillaceae Family on the Skin Surface of Broiler Chickens (Ross 308) Depending on the Nutritional Supplement and the Housing Conditions
}

\author{
Paulina Cholewińska ${ }^{1, * \mathbb{D}}$, Marta Michalak ${ }^{2}$, Konrad Wojnarowski ${ }^{1} \mathbb{D}$, Szymon Skowera $^{1}$, Jakub Smoliński ${ }^{1}$ \\ and Katarzyna Czyż ${ }^{1}$ (D) \\ 1 Institute of Animal Breeding, Wroclaw University of Environmental and Life Sciences, \\ 51-630 Wroclaw, Poland; konrad.wojnarowski@upwr.edu.pl (K.W.); 119633@student.upwr.edu.pl (S.S.); \\ 107848@student.upwr.edu.pl (J.S.); katarzyna.czyz@upwr.edu.pl (K.C.) \\ 2 Department of Animal Nutrition and Feed Management, Wroclaw University of Environmental and Life \\ Sciences, 51-630 Wroclaw, Poland; marta.michalak@upwr.edu.pl \\ * Correspondence: paulina.cholewinska@upwr.edu.pl
}

Citation: Cholewińska, P.; Michalak, M.; Wojnarowski, K.; Skowera, S.; Smoliński, J.; Czyż, K. Levels of Firmicutes, Actinobacteria Phyla and Lactobacillaceae Family on the Skin Surface of Broiler Chickens (Ross 308) Depending on the Nutritional Supplement and the Housing Conditions. Agriculture 2021, 11, 287. https://doi.org/10.3390/ agriculture11040287

Academic Editor: István Komlósi

Received: 22 February 2021

Accepted: 23 March 2021

Published: 26 March 2021

Publisher's Note: MDPI stays neutral with regard to jurisdictional claims in published maps and institutional affiliations.

Copyright: (c) 2021 by the authors. Licensee MDPI, Basel, Switzerland. This article is an open access article distributed under the terms and conditions of the Creative Commons Attribution (CC BY) license (https:// creativecommons.org/licenses/by/ $4.0 /)$.

\begin{abstract}
The microbiome of animals, both in the digestive tract and in the skin, plays an important role in protecting the host. The skin is one of the largest surface organs for animals; therefore, the destabilization of the microbiota on its surface can increase the risk of diseases that may adversely affect animals' health and production rates, including poultry. The aim of this study was to evaluate the effect of nutritional supplementation in the form of fermented rapeseed meal and housing conditions on the level of selected bacteria phyla (Firmicutes, Actinobacteria, and family Lactobacillaceae). The study was performed on 30 specimens of broiler chickens (Ross 308), individually kept in metabolic cages for 36 days. They were divided into 5 groups depending on the feed received. On day 36, skin swabs were individually collected. Temperature and humidity were measured in the room. The temperature was measured every 2 days (18 measurements $\times 6$ points). The results of Real-Time PCR analysis have shown a significant effect of the feed additive on the level of Firmicutes phylum on the skin. On the other hand, a variable level of the tested bacteria was shown depending on the location of the cages. The Firmicutes phylum and Lactobacillaceae family achieved the highest level in the top-window zone. However, in the case of the Actinobacteria phylum, the highest level was found at the top-door and middle-door zones. The obtained results suggest that the conditions in which animals live may affect the microbiota of their skin.
\end{abstract}

Keywords: skin microbiota; poultry; welfare; diet

\section{Introduction}

Poultry, and in particular domestic chickens (Gallus gallus domesticus), is one of the main sources of animal protein due to one of the best feed/meat conversion ratios [1]. Due to humanitarian reasons and the production volume itself, it is important to maintain adequate welfare when keeping animals [2]. One of the welfare aspects is avoiding animal exposure to mechanical injuries possibility [3], which often result in disruption of the skin continuity, which may lead to many bacterial diseases [4]. It is not, however, the only circumstance related to the skin that we should pay attention to when keeping animals.

The skin of vertebrates is one of the largest organs in terms of surface, and for decades it has been attributed mainly to the role of an insulator separating the internal system of animals from the external environment. Over time, however, our knowledge about the skin and the roles and mechanisms occurring within or on its surface has grown significantly [5]. We already know that the protective barrier function is maintained not only by ectoderm cells but also by bacteria living on the surface of the skin, creating a specific ecosystem-a 
microbiota that, in order to fulfill its proper function, requires a balance both in terms of the species composition itself and the prevailing physicochemical conditions [6,7]. Factors such as nutrition, temperature, humidity and sunlight may affect the structure of the microbiota, which may directly affect animal health, and therefore, generate higher breeding costs [6]. The microbiota consists of bacteria, protozoa, fungi and archaea. However, bacteria are the most abundant both inside the body and on the skin. In mammals, the most numerous groups of bacteria belong to the Firmicutes and Bacteroidetes phyla. Yet, on the skin itself, bacteria from the Firmicutes, Bacteroidetes, Actinobacteria and Proteobacteria phyla are largely present; however, it depends on the taxon and even the species of the animal or the place where it lives [8]. Unfortunately, in the case of broiler chickens, no tests were carried out to systematize the correct microbiological composition, which in the future may provide additional information about their health status and thus their welfare.

The use of feed additives, including fermented feed, may affect the microbiological composition of the digestive system, increasing the amount of, e.g., bacteria from the Lactobacillaceae family. Changes in the gut can have an impact on overall health status [9] and thus also on the skin [10]. However, this relationship has not yet been thoroughly investigated for broiler chickens and should be undertaken in the future, and was also the reason for conducting the research presented in this paper.

This research focuses on the effects of nutrition and the housing environment on the levels of selected bacteria phyla on the skin of caged broiler chickens.

\section{Materials and Methods}

\subsection{Animals}

The research was conducted on 30 broiler chickens (Ross 308, male) kept in metabolic cages ( 1 broiler chicken per cage). The animals were kept in cages from the first day of life. They were divided into 5 food groups, 6 chickens per group (Table 1):

- $\quad$ A-control (no rapeseed meal);

- $\quad$ B-addition of $5 \%$ of standard rapeseed meal;

- C-addition of $10 \%$ of standard rapeseed meal;

- $\quad \mathrm{D}$-addition of 5\% standard rapeseed meal and 5\% fermented rapeseed meal;

- E-addition of $10 \%$ standard rapeseed meal and $10 \%$ fermented rapeseed meal.

Table 1. Nutritional composition of experimental diets.

\begin{tabular}{cccccccc}
\hline Mixture & Group & $\begin{array}{c}\text { Dry Matter } \\
\mathbf{( \% )}\end{array}$ & $\begin{array}{c}\text { Ash } \\
\mathbf{( \% )}\end{array}$ & $\begin{array}{c}\text { Protein } \\
\mathbf{( \% )}\end{array}$ & Fat (\%) & $\begin{array}{c}\text { Fiber } \\
\mathbf{( \% )}\end{array}$ & $\begin{array}{c}\text { Gross } \\
\text { Energy } \\
\text { (kcal) }\end{array}$ \\
\hline & A & 87.94 & 4.46 & 21.90 & 7.63 & 7.24 & 4275.29 \\
Starter & $\mathrm{B}$ & 87.90 & 3.99 & 20.77 & 7.45 & 7.39 & 4252.56 \\
(Day: & $\mathrm{C}$ & 87.70 & 4.17 & 22.78 & 7.81 & 7.67 & 4306.74 \\
1-7) & $\mathrm{D}$ & 87.63 & 4.41 & 22.37 & 7.72 & 7.53 & 4293.92 \\
& $\mathrm{E}$ & 87.99 & 4.83 & 24.07 & 7.41 & 7.10 & 4243.74 \\
\hline & $\mathrm{A}$ & 89.17 & 6.33 & 19.98 & 8.11 & 7.62 & 4268.95 \\
Grower 1 & $\mathrm{B}$ & 89.03 & 5.95 & 19.25 & 7.80 & 6.92 & 4247.90 \\
(Day: & $\mathrm{C}$ & 89.37 & 6.41 & 19.83 & 8.27 & 6.61 & 4246.39 \\
8-28) & $\mathrm{D}$ & 89.16 & 5.90 & 20.67 & 8.60 & 6.55 & 4294.93 \\
& $\mathrm{E}$ & 89.59 & 5.92 & 20.23 & 7.87 & 7.41 & 4308.50 \\
\hline & $\mathrm{A}$ & 89.76 & 6.58 & 20.85 & 8.90 & 6.01 & 4356.83 \\
Grower 2 & $\mathrm{B}$ & 89.90 & 5.98 & 20.77 & 9.89 & 6.17 & 4398.55 \\
(Day: & $\mathrm{C}$ & 89.58 & 6.02 & 20.22 & 9.62 & 8.11 & 4364.70 \\
28-35) & $\mathrm{D}$ & 89.74 & 6.40 & 20.61 & 9.02 & 6.31 & 4358.05 \\
& $\mathrm{E}$ & 89.57 & 6.62 & 20.90 & 8.86 & 8.61 & 4327.62 \\
\hline
\end{tabular}


They received feed and water ad libitum.

The composition of the additive fermented rapeseed meal: protein $29 \%$, fiber $10 \%$, lactic acid $6 \%, \mathrm{LAB}$ (lactic acid bacteria) $\log 6-7$, glucosinolate reduction.

The room temperature from day 1 was about $32{ }^{\circ} \mathrm{C}$; then it was gradually lowered by about 0.5 to $1{ }^{\circ} \mathrm{C}$ until the 20th day to obtain the temperature of $21^{\circ} \mathrm{C}$, at which it was kept until the sampling and weighing day. Humidity in the rooms during their rearing ranged from $60-70 \%$. During the day, they had no access to external light. The only source of light was automatic lighting from 6.00 to 23.00 throughout the entire period of their maintenance. The lighting on both sides of the cages ranged between 24 to 20 lux from top to bottom; LED lighting was used.

The condition of the tested animals was good, and they did not show any symptoms, such as diarrhea, skin problems, increased body temperature, lack of appetite, and apathy, etc.

The authors confirm that the ethical policies of the journal were adhered to. All animals that qualified for the study were subjected to standard procedures without any harm or discomfort. The study did not require the consent of the Local Ethical Committee for Animal Experiments (Act of 15 January 2015 on protection animals used for scientific or educational purposes), OJ 2015, 266, implementing the Directive 2010/63/EU of the European Parliament and the Council of 22 September 2010 on the protection of animals used for scientific purposes.

\subsection{Sampling}

Samples were collected on the 36th day of age individually from each animal in the area around the neck. Feathers were trimmed on a small area so the swabs would not have contact with them. Skin swabs were collected with sterile brushes, placed in test tubes with sterile water, and then frozen at $-26{ }^{\circ} \mathrm{C}$ until analysis ( 5 days).

\subsection{Assessment of the Housing Environment}

Throughout the experimental period, the maintenance conditions were assessed, the differences in temperature between the arrangement of the cages (top, middle and bottom of the cages, as well as on the door and window side) were examined (Table 2). The temperature was measured every 2 days ( 18 measurements $\times 6$ points). The arrangement of the cages in the room is shown in the diagram below (Figure 1). Additionally, the room humidity was measured at the same points, but its range was constant-SD (Standard Deviation) $=5.25$.

Table 2. Average differences in room temperature depending on the arrangement of cages $\left({ }^{\circ} \mathrm{C}\right)$ in relation to the general room temperature.

\begin{tabular}{ccccccc}
\hline $\begin{array}{c}\text { Cage } \\
\text { Position }\end{array}$ & $\begin{array}{c}\text { Top/ } \\
\text { Window }\end{array}$ & Top/ Door & $\begin{array}{c}\text { Middle/ } \\
\text { Door }\end{array}$ & $\begin{array}{c}\text { Middle/ } \\
\text { Window }\end{array}$ & $\begin{array}{c}\text { Bottom/ } \\
\text { Window }\end{array}$ & $\begin{array}{c}\text { Bottom/ } \\
\text { Door }\end{array}$ \\
\hline Mean & +1.05 & $+/-0.42$ & $+/-0.31$ & +0.61 & -0.65 & -0.44 \\
SD & 0.30 & 0.28 & 0.34 & 0.15 & 0.15 & 0.35 \\
\hline
\end{tabular}

SD-Standard devation. 


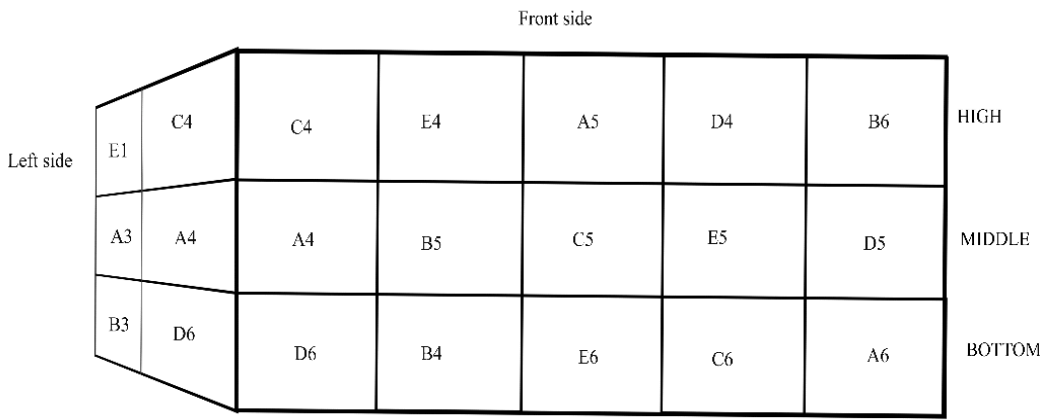

\begin{tabular}{|c|c|c|c|c|c|c|c|}
\hline $\mathrm{Al}_{1}$ & B1 & Dl & $\mathrm{Cl}$ & El & E1 & $\mathrm{C} 4$ & Left side \\
\hline $\mathrm{C} 2$ & E2 & B2 & D2 & A3 & $\Lambda 3$ & $\Lambda 4$ & MIDDLE \\
\hline 103 & $\mathrm{C} 3$ & A2 & E6 & B3 & B3 & D6 & ВОТТОМ \\
\hline
\end{tabular}

Figure 1. Diagram presenting arrangement of individual digestibility cages.

\subsection{DNA (Deoxyrybonucleic acid) Isolation}

A genomic bacteria AX Mini (A\&A Biotechnology, Gdansk, Poland) was used for DNA isolation. The quality of DNA obtained as a result of isolation was verified using the NanoDrop 2000 spectrophotometer (Thermo Scientific, Wilmington, NC, USA). The average DNA content was $90-110 \mu \mathrm{g} / \mu \mathrm{L}$. The level of impurities in the samples was as follows: for parameter 260/230:2.0-2.2 and for parameter 260/280:1.8-2.0 (in accordance with the guidelines from Thermo Scientific). When high levels of impurity or low-quality DNA were found, the samples were isolated again or purified using a clean-up concentrator (A\&A Biotechnology, Gdansk, Poland).

\subsection{Real-Time PCR Analysis}

Bio-Rad CFX Connect 96 Touch apparatus was used to perform real-time PCR (Polymerase Chain Reaction) analysis. Bio-Rad SsoAdvanced ${ }^{\mathrm{TM}}$ Universal SYBR ${ }^{\circledR}$ Green Supermix kit (Bio-Rad Laboratories, Inc., Hercules CA, USA) at a volume of $10 \mu \mathrm{L}$ was applied in 3 technical repetitions (Table 3). A NTC test (no template control) was additionally performed for each gene. The strategy of RT-PCR analysis involved the amplification of genes specific for the examined phyla in the presence of the reference gene for all bacteria (Table 4) [10,11]. 
Table 3. PCR mix components.

\begin{tabular}{cc}
\hline Component & Volume in $\mathbf{1 0} \boldsymbol{\mu L}$ of Reaction \\
\hline SsoAdvanced $^{\mathrm{TM}}$ Universal SYBR & \\
Supermix & Green \\
Starter (Foward + Reverse) & $5 \mu \mathrm{L}$ \\
Matrix DNA & $1 \mu \mathrm{L}(0.8 \mu \mathrm{M})$ \\
Sterile water & $2 \mu \mathrm{L}\left(0.04-0.015 \times 10^{-4}\right)$ \\
$2 \mu \mathrm{L}$ \\
\hline
\end{tabular}

PCR-Polymerase Chain Reaction.

Table 4. Primers used during RT-PCR.

\begin{tabular}{|c|c|c|c|}
\hline Name & Forward $\left(5^{\prime}-3^{\prime}\right)$ & Reverse $\left(5^{\prime}-3^{\prime}\right)$ & Source \\
\hline $\begin{array}{l}\text { Universal Eubacterial } \\
\text { genes }\end{array}$ & $\begin{array}{l}\text { 530F (5'-GTC CCA } \\
\text { GCM GCN GCG G) }\end{array}$ & $\begin{array}{c}\text { 1100R (5'-GGG TTN } \\
\text { CGN TCG TTG) }\end{array}$ & [12] \\
\hline Firmicutes & $\begin{array}{c}\text { 928F-Firm }\left(5^{\prime}-\mathrm{TGA}\right. \\
\text { AAC TYA AAG GAA } \\
\text { TTG ACG) }\end{array}$ & $\begin{array}{l}\text { 1040FirmR }\left(5^{\prime}-\text { ACC }\right. \\
\text { ATG CAC CTG TC) }\end{array}$ & [13] \\
\hline Actinobacteria & $\begin{array}{l}\text { Act1159R TCCGAGT- } \\
\text { TRACCCCGGC }\end{array}$ & $\begin{array}{c}\text { Eub338F ACGGGCG- } \\
\text { GTGTGTACA }\end{array}$ & [14] \\
\hline Lactobacillaceae & $\begin{array}{c}\text { lac1 forward }\left(5^{\prime}-\text { AGC }\right. \\
\text { AGT AGG GAA TCT } \\
\text { TCC A) }\end{array}$ & $\begin{array}{c}\text { Lac2Seq }\left(5^{\prime}-\right. \\
\text { ATTTCACCGCTACACATG })\end{array}$ & [15] \\
\hline
\end{tabular}

RT-PCR-Real Time Polymerase Chain Recation.

In order to determine the performance of individual genes, a standard curve was drawn for the genes under the study. A sample dilution of $10^{-3}$ was selected for analysis (from the $10^{-1}$ to $10^{-7}$ series). The analysis was performed in accordance with a 40 cycles protocol: polymerase activation and DNA denaturation $95^{\circ} \mathrm{C}(3 \mathrm{~min})$, denaturation $95^{\circ} \mathrm{C}$ $(15 \mathrm{~s})$, annealing $60.5^{\circ} \mathrm{C}(15 \mathrm{~s})$, extension and plate reading at $72^{\circ} \mathrm{C}(40 \mathrm{~s})$. The melting curves analysis for the samples was performed at temperatures ranging from $65^{\circ} \mathrm{C}(5 \mathrm{~s})$ to $95{ }^{\circ} \mathrm{C}\left(0.5^{\circ} \mathrm{C}\right.$ increments in $\left.2 \mathrm{~s}\right)$.

The data obtained were then processed using the CFX Maestro software v. 1.1 (Bio-Rad Laboratories, Inc., Hercules CA, USA). The sample with a DNA level of $100 \mu \mathrm{g} / \mu \mathrm{L}$ and impurities at a level consistent with the standards was an arbitrary calibrator. The efficiency of individual primers was normal (in accordance with the standards established by Bio-Rad) and amounted to $89.4 \%$ for Firmicutes, $93.6 \%$ for Actinobacteria, 97.7\% for Lactobacillaceae; Universal-94.4. CFX Maestro calculated the results from the number of the reference gene matrix and the differences at the relative normalized expression $\left(\mathrm{RNE}=\Delta \Delta \mathrm{C}_{\mathrm{q}}\right)$ phylum's level, taking into account the amplification efficiency of individual genes [10].

\subsection{Statistical Analysis}

The results were analyzed with the use of the Statistica software (v. 13.3, StatSoft Inc., Tulsa, OK, USA). The data distribution was checked with the Shapiro-Wilk test. The data relating to the bodyweight of the chickens were analyzed using the ANOVA (analysis of variance) test, while the remaining data (no normal distribution) using the Wilcoxon pair test and the Friedman ANOVA $(p>0.05)$. The differences in the case of the ANOVA test were determined using Tukey's test.

\section{Results}

The weighing performed on the 36th day of life showed that the group with the addition of $5 \%$ standard rapeseed meal and 5\% fermented rapeseed meal (D) had the highest body weight. On the other hand, the lowest body weight was found in individuals from the group with the addition of 5\% of standard rapeseed meal (Table 5). Additionally, the performed statistical analysis in terms of the arrangement of cages (level and sidewindow/door) did not show any significant statistical differences. 
Table 5. Bodyweight of broiler chickens at 36 days of age (g).

\begin{tabular}{cccccc}
\hline Group & A & B & C & D & E \\
\hline Mean & $1729.92^{\text {a }}$ & $1615.83^{\mathrm{A}}$ & $1707.29^{\mathrm{A}}$ & $1920.76^{\mathrm{B}, \mathrm{b}}$ & $1642.57^{\mathrm{A}}$ \\
SD & $79.17^{\mathrm{n}}$ & 66.05 & $129.68^{-1}$ & 83.98 & 33.18 \\
\hline
\end{tabular}

$p>0.05-\mathrm{a}, \mathrm{b} ; p>0.01-\mathrm{A}, \mathrm{B}$.

The analysis of the RT-PCR results showed that the group fed with $10 \%$ standard rapeseed meal $(\mathrm{C})$ had a significantly higher RNE level of Firmicutes compared to the group fed with 10\% fermented rapeseed meal and 10\% standard (E). In addition, this level was generally the highest also compared to the other nutritional groups; similar trends are also visible in the comparison of the level of Actinobacteria and the Lactobacillaceae family. The lowest level of the Actinobacteria phylum was characteristic for the control group (A), and the highest, the aforementioned group C. The lowest level of the Lactobacillaceae family was characteristic for group B-5\% addition of standard rapeseed meal (Figure 2).

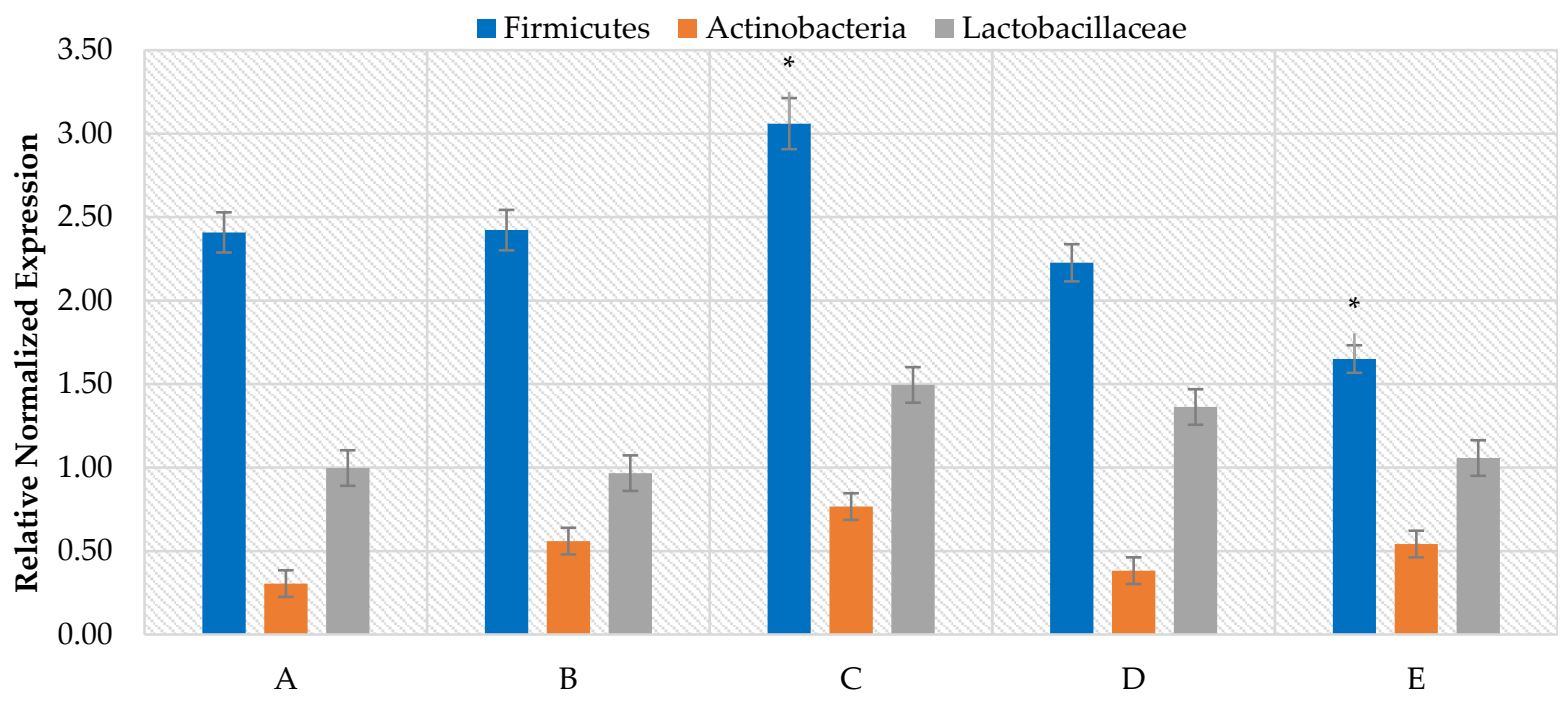

Figure 2. Level of relative normalized expression (RNE) of Firmicutes, Actinobacteria phyla and Lactobacillaceae family depending on the nutritional supplement. ${ }^{*} p=0.048$. (A)—control (no rapeseed meal); (B)—addition of $5 \%$ of standard rapeseed meal; (C) —addition of 10\% of standard rapeseed meal; (D) -addition of 5\% standard rapeseed meal and $5 \%$ fermented rapeseed meal; (E)_addition of 10\% standard rapeseed meal and 10\% fermented rapeseed meal.

The analysis of the level of selected bacterial phyla also showed differences depending on the arrangement of the cages. The animals placed in the highest cages differed in the level of the Firmicutes phylum depending on the side of the location-doors or windows. In the window-up zone, animals were characterized by a much higher level (about 3 times) of this phylum compared to the up-door zone (Figure 3). Additionally, the temperature in the window-top sector was on average higher by $1.05^{\circ} \mathrm{C}$, and on the door side by $0.4^{\circ} \mathrm{C}$. Similar results were also obtained in the case of the Lactobacillaceae family, where the difference between the RNE level was more than twofold (Figure 4). Significant differences were also observed for the Actinobacteria phylum (Figure 5). The most significant differences in the level of the phyla were between the top-window and top-door zones. The highest RNE level was found in the middle cages in the middle-door zone, while the lowest in the upper part in the top-window zone. 
- Door side $\quad \square$ Windows side

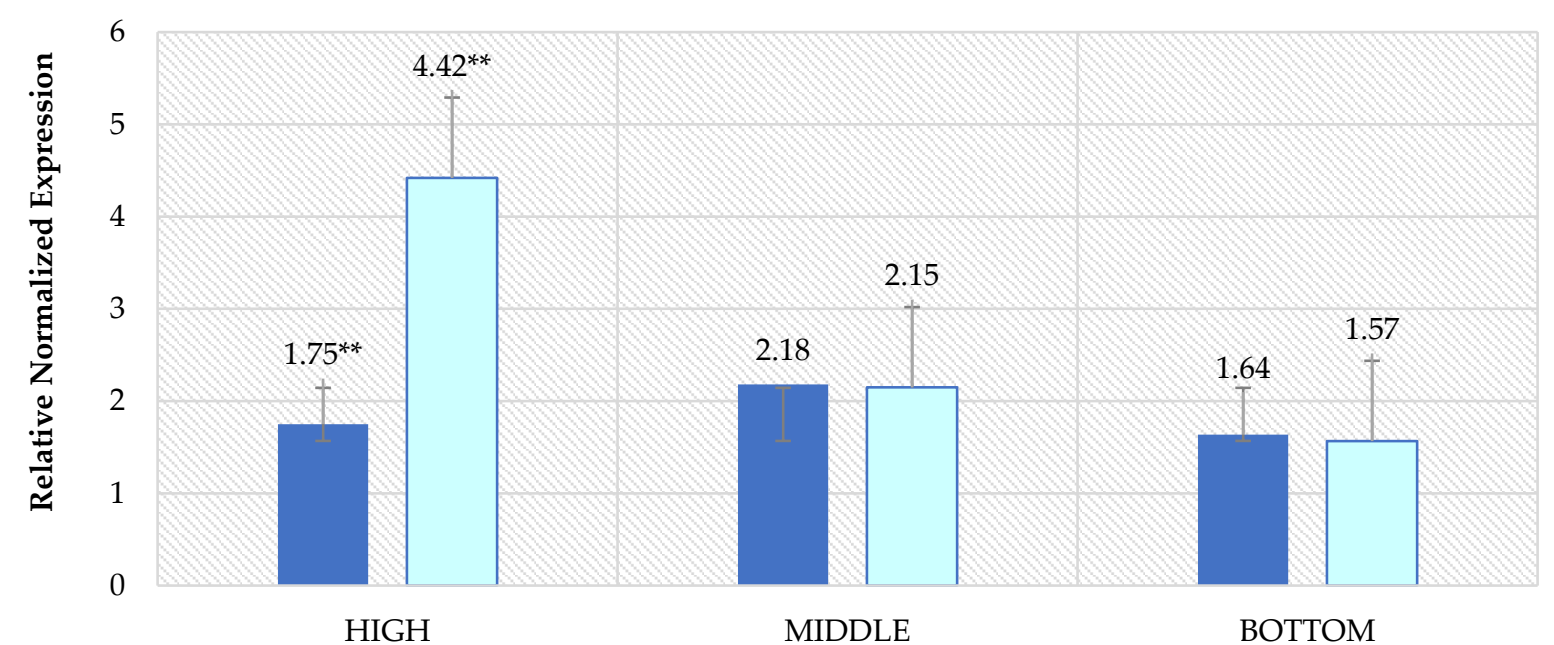

Figure 3. Level of relative normalized expression (RNE) of Firmicutes depending on the cage setting. ${ }^{* *} p=0.00427$.

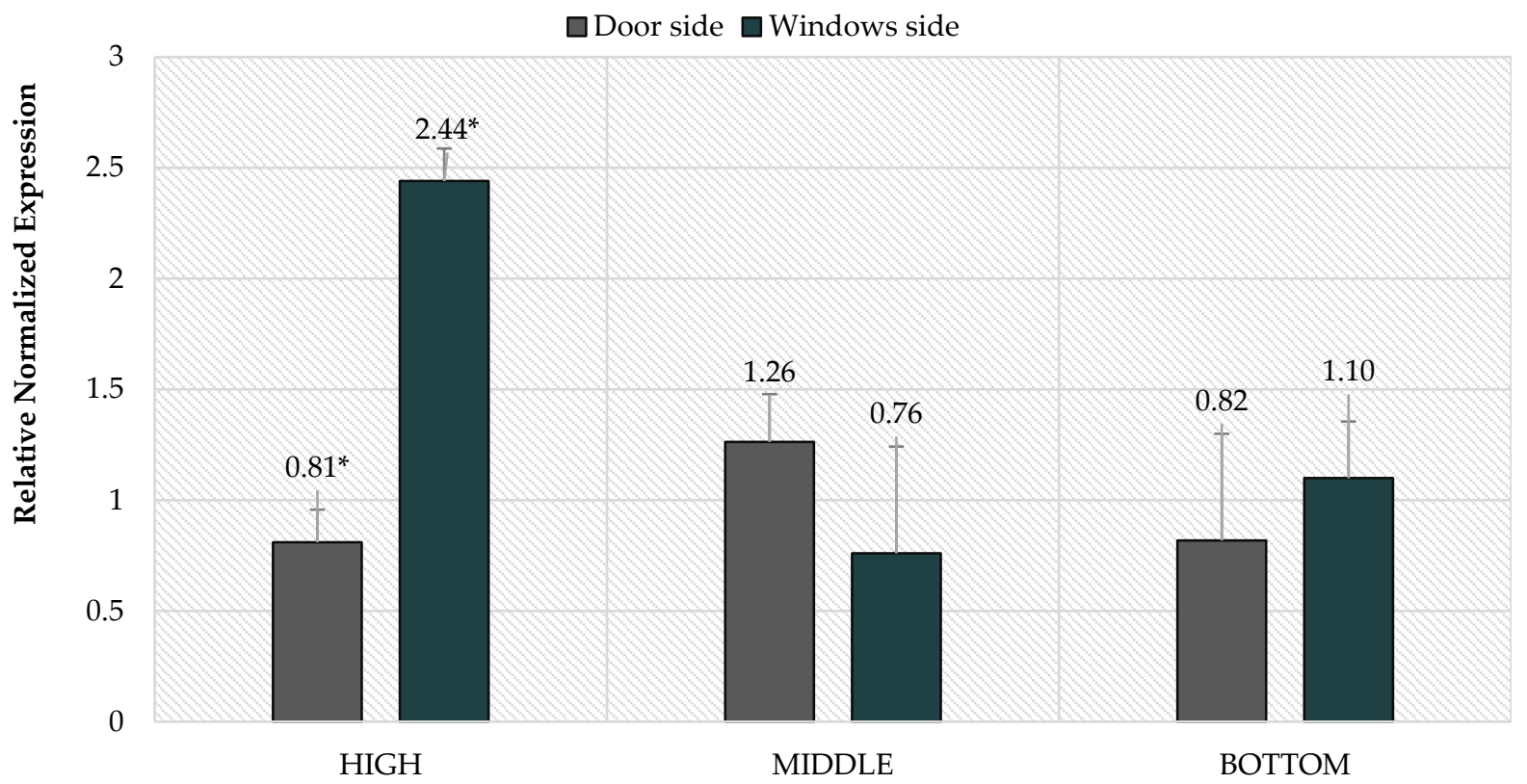

Figure 4. Level of relative normalized expression (RNE) of Lactobacillaceae family depending on the cage setting. $* p=0.0428$.

However, when analyzing only the position of the cages in terms of height, significant differences were shown only in the level of the Firmicutes phylum (Figure 6). The highest level of this phylum was characterized by the groups staying in the upper cages and the lowest in the lowest cages. There is also a downward trend in RNE levels in the Lactobacillaceae family. On the other hand, in the case of the Actinobacteria phylum, there is a slight upward trend between individuals housed in the upper and lower cages. However, the highest level occurred in the middle frames. On the other hand, when analyzing the level of the tested bacteria broken down into the window and door zones only, no significant differences in the RNE level were found. 
$\square$ Door side $\square$ Windows side

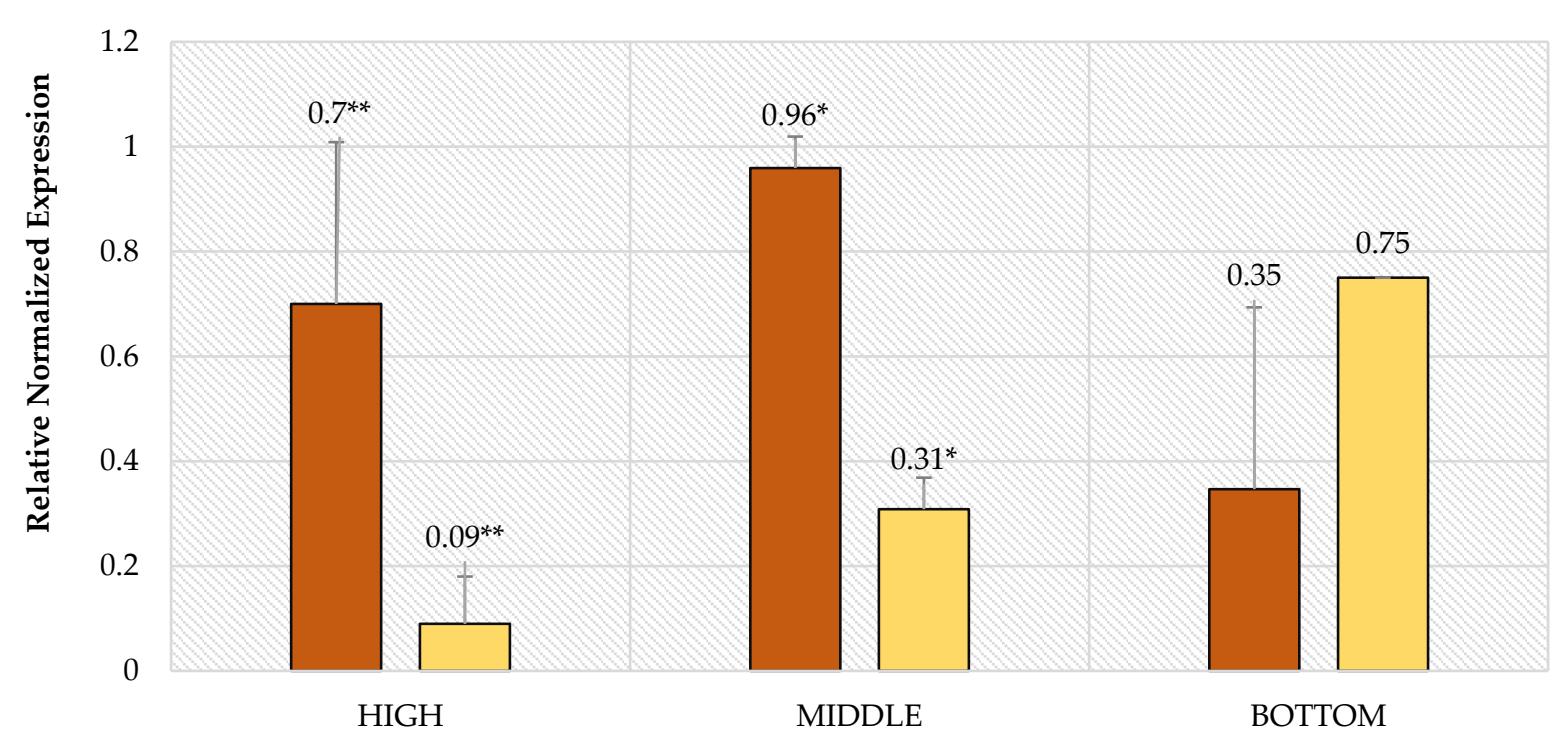

Figure 5. Level of relative normalized expression (RNE) of Actinobacteria phylum depending on the cage setting. ${ }^{* *} p=0.00427 ;{ }^{*} p=0.046$.

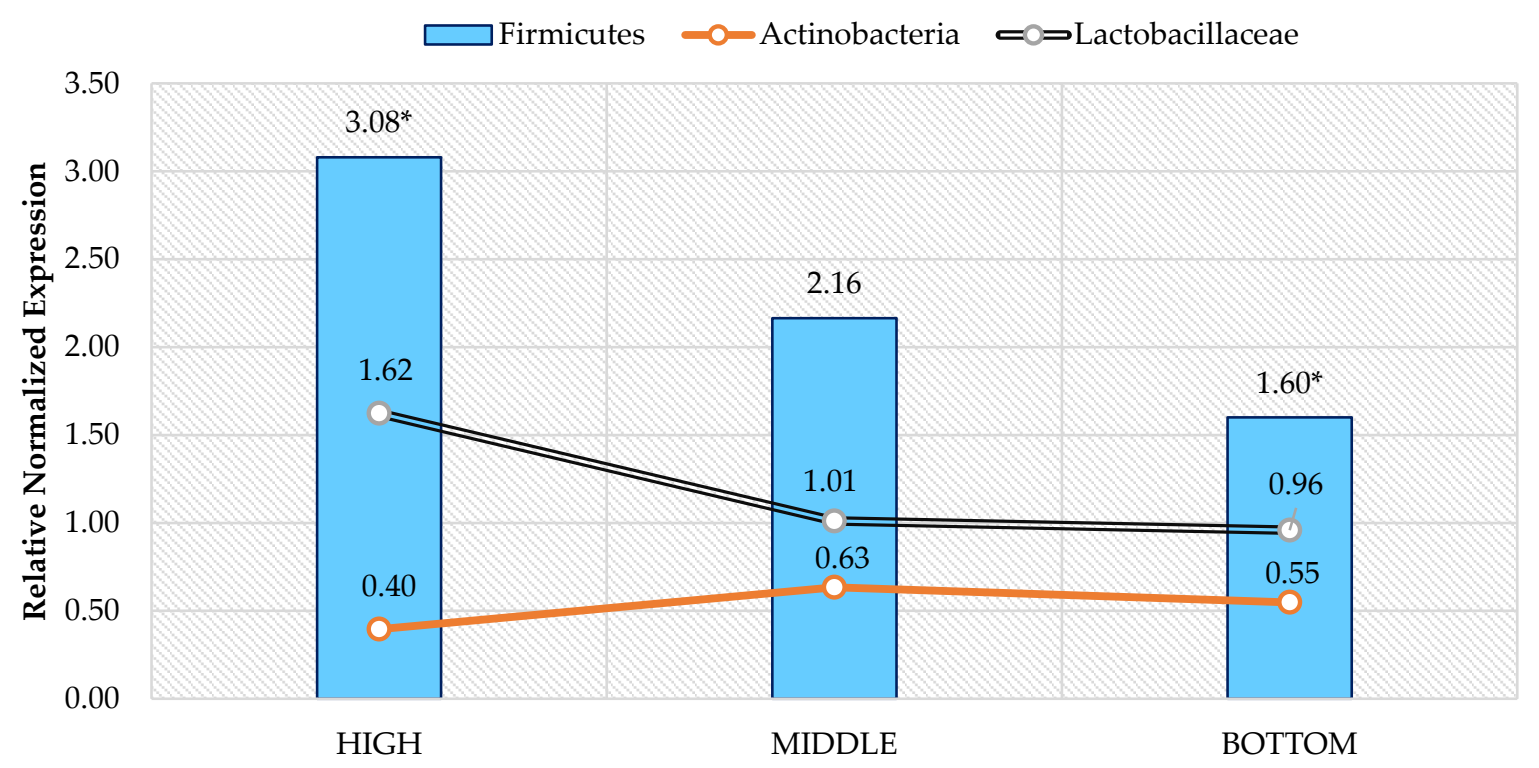

Figure 6. The level of studied phyla and families depending on the height of the cages. * $p=0.038$.

\section{Discussion}

The microbial composition of the skin and the digestive tract is important because of its role in regulating the immune system and overall health status maintenance $[16,17]$. The skin microbiota changes with age but is somewhat stable in adult animals. In the case of animals, the main factors influencing the composition of their skin microbiome are environment, diet, livelihood, and geographical area $[6,18,19]$. In the experiment carried out on adult animals, it was shown that depending on the feed supplement obtained; there were differences in the level of the Firmicutes phylum on the skin surface. The group with the addition of $10 \%$ rapeseed meal (C) had the highest level of this phylum, while the group with the addition of $10 \%$ standard rapeseed meal and 10\% fermented rapeseed meal had the lowest level of this phylum. Statistical differences were observed only in the case 
of Firmicutes phylum. Such a phenomenon, diet affecting microbiota of the skin, has been observed previously for felines and humans [20-22] but not for poultry.

The housing conditions and animal welfare of livestock, including poultry, can influence the microbiological composition of the organism. Research and analyses conducted by, among others, Hoffman et al. [8] or Ross et al. [6] indicate that the environment in which animals are kept may affect the skin microbiota. In the conducted study, there were observed statistical differences between groups on the basis of the cage arrangement. The highest level of the Firmicutes phylum has been observed in the case of individuals located the highest from the side of the windows; similar results were obtained in the case of the Lactobacillaceae family; in addition, the highest temperature was recorded in this place. Taking into account the sensitivity of bacteria to changing environmental conditions, the bacteria on the skin surface are the most sensitive to changes, because even despite the constant internal temperature of the host, the temperature of the skin surface also depends on the environment in which it lives [23-25]. However, for this phylum and family, no significant differences were found in the lower and mid-level cages, which may have been due to a more stable holding temperature.

On the other hand, the greatest differentiation occurred at the level of the Actinobacteria phylum. Its highest level occurred in the cages arranged in the middle part from the side of the door, and an equally high-level occurred in the upper part of the cages on the same side. The upper part from the window side had the highest temperature in the room, and the middle part from the same side was also slightly higher than the general temperature, which could have influenced the higher level of this phylum from the door side, where the temperature was usually lower. Similar relationships also occurred at the lower level; in this part, the temperature was generally slightly lower on the window side and slightly higher on the door side. This indicates that this phylum is better kept at a slightly lower temperature than the aforementioned bacteria and allows the conclusion that its level, as in the case of the others, is also dependent on the temperature on the skin surface [26-28]. As can be seen, despite the presence of the animals in the same room, the studied phyla appeared at different levels, depending on the arrangement of the cages. This indicates that the housing system in the case of poultry can significantly affect the microbiological composition of its skin. Both Firmicutes and Actinobacteria phyla are characterized by bacteria that have a positive effect on the condition of the skin and are relatively pathogenic. In the Actinobacteria phylum, these include, but are not limited to, C. amicolatum, C. striatum, C. jeikeium, C. urealyticum, and C. xerosis. In the case of the Firmicutes phyla, these are, for example, Staphylococcus epidermidis. Disturbance of homeostasis in the composition of the microbiota may result in an increased risk of skin diseases $[16,17,27,28]$.

Due to the lack of similar studies, it is not possible to unequivocally assess the impact of individual factors included in the experiment. Most of the studies performed on broilers were focusing only on microbiota associated with the digestive tract. There is a clearly visible lack of studies focused on chicken skin microbiota; thus given issue requires further research and analysis. In addition, in the future, this type of research should be performed using sequencing to detect as many bacteria on the skin as possible, as was the case with humans.

\section{Conclusions}

The conducted experiment showed that the diet had a significant effect on broilers' skin microbiota in terms of Firmicutes phylum. Additionally, environmental factors related to the keeping of animals - the location of cages-also had a significant impact on levels of selected bacteria. It has been shown that, depending on their arrangement, there may be changes in the level of Firmicutes (including the Lactobacillaceae family) and Actinobacteria phyla, depending on the ambient temperature. These changes indicate that normalizing the conditions in the room where animals are located may positively impact their skin microbiota and thus their health. 
Author Contributions: Conceptualization, M.M., K.W. and P.C.; methodology M.M., P.C.; formal analysis, P.C., K.W. and M.M.; investigation, S.S., J.S. and P.C.; data curation, P.C., K.W.; writingoriginal draft preparation, P.C. and M.M.; writing_review and editing, J.S. and K.W.; visualization, P.C., J.S., S.S.; supervision, K.C.; project administration, K.C. All authors have read and agreed to the published version of the manuscript.

Funding: This research received no external funding.

Institutional Review Board Statement: All animals that qualified for the study were subjected to standard procedures without any harm or discomfort, and therefore, the study did not require the consent of the Local Ethical Commission for Animal Experiments at the Institute of Immunology and Experimental Therapy of the Polish Academy of Sciences in Wroclaw, Poland (Act of 15 January 2015 on protection animals used for scientific or educational purposes).

Informed Consent Statement: Not applicable.

Data Availability Statement: The data presented in this study are available on request from the corresponding author. The data are not publicly available due to privacy.

Acknowledgments: The authors would like to thank Magdalena Wołoszyńska (Department of Genetics, Wroclaw University of Environmental and Life Sciences, 51-630 Wroclaw, Poland) for the access to the equipment.

Conflicts of Interest: All authors declare no conflict of interest.

\section{References}

1. FAO. 2017. Available online: http://www.fao.org/poultry-production-products/production/en/ (accessed on 9 January 2021).

2. Cholewińska, P.; Górniak, W.; Wojnarowski, K. Impact of selected environmental factors on microbiome of the digestive tract of ruminants. BMC Vet. Res. 2021, 17, 1-10. [CrossRef]

3. Weeks, C.A.; Lambton, S.L.; Williams, A.G. Implications for welfare, productivity and sustainability of the variation in reported levels of mortality for laying hen flocks kept in different housing systems: A meta-analysis of ten studies. PLoS ONE 2016, 11, e0146394. [CrossRef]

4. Atterbury, R.J.; Gigante, A.M.; Lozano, M.D.L.S.R.; Medina, R.D.M.; Robinson, G.; Alloush, H.; Allen, V.M. Reduction of salmonella contamination on the surface of chicken skin using bacteriophage. Virol. J. 2020, 17, 1-8. [CrossRef]

5. Jablonski, N.G. Skin: A Natural History; University of California Press: Berkeley, CA, USA, 2008.

6. Ross, A.A.; Rodrigues Hoffmann, A.; Neufeld, J.D. The skin microbiome of vertebrates. Microbiome 2019, 7, 79. [CrossRef]

7. Nagase, S.; Ogai, K.; Urai, T.; Shibata, K.; Matsubara, E.; Mukai, K.; Okamoto, S. Distinct skin microbiome and skin physiological functions between bedridden older patients and healthy people: A single-center study in Japan. Front. Med. 2020, 7, 101. [CrossRef]

8. Hoffmann, A.R. The cutaneous ecosystem: The roles of the skin microbiome in health and its association with inflammatory skin conditions in humans and animals. Adv. Vet. Dermatol. 2017, 8, 71-83.

9. Naji, S.A.H.; AI-Zanili, I.F.B.; AI-Gharawi, J. The effect of feed wetting and fermentation on the intestinal flora, humoral and cellular immunity of broiler chicks. Int. J. Adv. Res. 2015, 3, 87-94.

10. Brandwein, M.; Katz, I.; Katz, A.; Kohen, R. Beyond the gut: Skin microbiome compositional changes are associated with BMI. Hum. Microbiome J. 2019, 13, 100063. [CrossRef]

11. Górniak, W.; Cholewińska, P.; Szeligowska, N.; Wołoszyńska, M.; Soroko, M.; Czyż, K. Effect of intense exercise on the level of bacteroidetes and Firmicutes phyla in the digestive system of thoroughbred racehorses. Animals 2021, 11, 290. [CrossRef] [PubMed]

12. Dowd, S.E.; Callaway, T.R.; Wolcott, R.D.; Sun, Y.; McKeehan, T.; Hagevoort, R.G.; Edrington, T.S. Evaluation of the bacterial diversity in the feces of cattle using $16 \mathrm{~S}$ rDNA bacterial tag-encoded FLX amplicon pyrosequencing (bTEFAP). BMC Microbiol. 2008, 8, 1-8. [CrossRef]

13. De Gregoris, T.B.; Aldred, N.; Clare, A.S.; Burgess, J.G. Improvement of phylum-and class-specific primers for real-time PCR quantification of bacterial taxa. J. Microbiol. Methods 2011, 86, 351-356. [CrossRef]

14. Blackwood, C.B.; Oaks, A.; Buyer, J.S. Phylum-And class-specific PCR primers for general microbial community analysis. Appl. Environ. Microbiol. 2005, 71, 6193-6198. [CrossRef]

15. Walter, J.; Hertel, C.; Tannock, G.W.; Lis, C.M.; Munro, K.; Hammes, W.P. Detection of lactobacillus, pediococcus, leuconostoc, and weissella species in human feces by using group-specific PCR primers and denaturing gradient gel electrophoresis. Appl. Environ. Microbiol. 2001, 67, 2578-2585. [CrossRef]

16. Yan, D.; Issa, N.; Afifi, L. The Role of the skin and gut microbiome in psoriatic disease. Curr. Dermatol. Rep. 2017, 6, 94-103. [CrossRef]

17. Xiao, Y.; Yun, X.; Weidong, Z.; Jinggang, C.; Kaifeng, L.; Hua, Y. Microbial community mapping in intestinal tract of broiler chicken. Poult. Sci. 2017, 96, 1387-1393. [CrossRef] 
18. Henderson, G.; Cox, F.; Ganesh, S.; Jonker, A.; Young, W.; Global Rumen Census Collaborators; Janssen, P.H. Rumen microbial community composition varies with diet and host, but a core microbiome is found across a wide geographical range. Sci. Rep. 2015, 5, 14567. [CrossRef] [PubMed]

19. Oakley, B.B.; Morales, C.A.; Line, J.; Berrang, M.E.; Meinersmann, R.J.; Tillman, G.E.; Wise, M.G.; Siragusa, G.R.; Hiett, K.L.; Seal, B.S. The poultry-associated microbiome: Network analysis and farm-to-fork characterizations. PLoS ONE 2013, 8, e57190. [CrossRef] [PubMed]

20. Older, C.E.; Diesel, A.B.; Lawhon, S.D.; Queiroz, C.R.; Henker, L.C.; Rodrigues Hoffmann, A. The feline cutaneous and oral microbiota are influenced by breed and environment. PLoS ONE 2019, 14, e0220463. [CrossRef] [PubMed]

21. Morvan, P.Y.; Vallee, R. Evaluation of the effects of stressful life on human skin microbiota. Appl. Microbiol. Open Access 2018, 4, $1-8$.

22. Lehtimäki, J.; Karkman, A.; Laatikainen, T.; Paalanen, L.; Von Hertzen, L.; Haahtela, T.; Ruokolainen, L. Patterns in the skin microbiota differ in children and teenagers between rural and urban environments. Sci. Rep. 2017, 7, 1-11. [CrossRef] [PubMed]

23. Shawkey, M.D.; Mills, K.L.; Dale, C. Microbial diversity of wild bird feathers revealed through culture-based and cultureindependent techniques. Microb. Ecol. 2005, 50, 40-47. [CrossRef] [PubMed]

24. Romanovsky, A.A. Skin temperature: Its role in thermoregulation. Acta Physiol. 2014, 210, 498-507. [CrossRef] [PubMed]

25. Theurer, M.E.; White, B.J.; Anderson, D.E.; Miesner, M.D.; Mosier, D.A.; Coetzee, J.F.; Amrine, D.E. Effect of transportation during periods of high ambitne temperature on physiologic ang behavioral indices of beef heifers. Am. J. Vet. Res. 2013, 74, 481-490. [CrossRef] [PubMed]

26. Jutte, L.S.; Merrick, M.A.; Ingersoll, C.D.; Edwards, J.E. The relationship between intramuscular temperature, skin temperature, and adipose thickness during cryotherapy and rewarming. Arch. Phys. Med. Rehabil. 2001, 82, 845-850. [CrossRef] [PubMed]

27. Li, W.; Ma, Z. FBA Ecological guild: Trio of firmicutes-bacteroidetes alliance against actinobacteria in human oral microbiome. Sci. Rep. 2020, 10, 287. [CrossRef]

28. Zhao, Y.; Qian, L.; Yuquan, W.; Hongyang, C.; Xu, Z.; Xueqin, W.; Si, S.; Zimin, W. Effect of actinobacteria agent inoculation methods on cellulose degradation during composting based on redundancy analysis. Bioresour. Technol. 2016, 219, 196-203. [CrossRef] [PubMed] 